\title{
Incentive Programmes as a Tool for Promoting Tourism in Bulgaria
}

\author{
Assoc. Prof. PhD Velina Kazandzhieva \\ University of Economics - Varna, Varna, Bulgaria \\ velina_kaz@ue-varna.bg
}

\begin{abstract}
Incentive (stimulating) programmes for travelling demonstrate recognition of the achievement of a company's employees through the opportunities for gathering tourist experience in interesting and attractive destination. Results from surveys reveal that $65 \%$ of the employees claim that they appreciate incentive travels more than any other form of reward and these travels are remembered longer than financial rewards. The goal set in this publication is: on the ground of a theoretical characteristic of the nature and specifics of the programmes for incentive travels to define and analyze the relevant trends in the industry and to make suggestions for improving and developing the stimulating travels in Bulgaria. Those travel programmes for reward and acknowledgment are not only an effective form of reward, they are also an intelligent investment with a considerable strategic potential for increasing the attractiveness of Bulgaria as a destination for incentive tourism.
\end{abstract}

Keywords: incentive travels, features, trends, opportunities, Bulgaria.

JEL Code: Z300; doi:10.36997/IJUSV-ESS/2019.8.1.27

\section{Introduction}

Incentive tourism is an effective managerial decision for achieving business goals through stimulating employees and partners with well-organized journeys and experiences worth remembering. When a company prepares a programme for an incentive trip, it usually combines the stay with extra activities and services in order to motivate, stimulate and reward its employees and partners. A relevant trend in incentive travels is short distances because of people's busy daily routines and their inability to be away from their offices for a long time. For this reason the organizers of these programmes would rather plan trips to close and accessible destinations where there are offered flexible conditions for various activities that comply with a particular topic.

Incentive tourism is a comparatively new segment in the tourist sector which recently has been developing with even higher rates. Accounting for about $7 \%$ of all business events activities, the Events Industry Council's (2018) Global Economic Impact study estimates the incentive travel industry to be worth around $\$ 75$ billion globally. In times of growing stress and dynamics at one's working place employees need rest to remember and encouragement. Incentive programmes are an element of MICE (Meeting, Incentive, Convention, Exhibitions) tourism and trips in these programmes are meant for collaborators, partners or clients of a particular company in order to encourage, stimulate and motivate them. The results and benefits of incentive tourism stimulate and accelerate its development which is one of the main reasons for its enlargement and the affirmation of its positions in the tourist industry. The positive effects of similar trips have significant practical dimensions in the business of any company because organized incentive events for the company employees increase the indicators of employees' productivity and the sums invested return repeatedly.

Incentive tourism is not only an effective tool for pulling teams together and increasing motivation, it is also an appropriate instrument for non-material encouragement with rationally invested finances for overall improvement of the organizations. Travels of the incentive type are characterized with standard corporate holidays with extra excursions, activities with unifying themes and scenario or extraordinary elements. These additional parameters of the incentive travels attract one's attention, arouse interest and inspiration. Their form allows for creating unique atmosphere - due to it one can achieve in the best way the goals set before the trip itself.

The subject of the survey in this article is incentive tourism and its object is the potential of incentive travels to be used as a tool for promoting Bulgarian tourism. The goal set in the 
publication is: on the ground of a theoretical characteristic of the nature and specifics of the programmes for incentives to define and analyze the relevant trends in the industry, and to make suggestions for improving and developing incentive travels in Bulgaria. There has been systematized the potential of the country in respect to incentive tourism and there have been elaborated the more important challenges and hindrances for its development. Key characteristic features of the nature of stimulating programmes have been defined and an analysis has been made of the modern changes in the incentive industry, as well as of their impacts. The recommendations for developing incentive tourism in Bulgaria are made in compliance with the global tendencies in the studied subject matter and the overall assessment of the tourist potential of the country.

\section{Definition and characteristic features of incentive travels}

An incentive (stimulating) travel is defined in various ways. The Society of Incentive and Travel Executives (SITE) defines it as "a global management tool that uses exceptional travel experience to motivate and/or recognize participants for increased level of performance in support of the organization goal" (Swarbrooke \& Horner, 2001, p. 11; SITE, 2019). Interestingly, incentive travel uses leisure tourism as a reward for good performance at work. It therefore bridges the divide between leisure tourism and business tourism. The Incentive Research Foundation (IRF) accepts a stimulating travel as "a motivational tool to enhance productivity or achieve other business objectives and the participants qualify for the travel award based on achieving the level of performance required by the program". Goldblatt and Nelson (2001) view travels as a reward in two aspects: - "a corporate sponsored meeting or trip to reward effort and create company loyalty, often built around a theme"; - "a celebratory event intended to showcase persons who meet or exceed sales or production goals." According to Pizman and Holcomb (2017) incentives are „travels provided to employees by companies in an effort to motivate them to increase and improve their performance. From the quoted definitions one can conclude the following basic characteristic features and functions of incentive travels:

$\checkmark$ they play a strongly stimulating role not only for the workers and employees of a certain company, but for its clients and partners as well;

$\checkmark$ they motivate the performance of tasks and activities and are at the same time a reward and recognition for achieving particular corporate goals;

$\checkmark$ they are always sponsored by the companies irrespective of the fact that their elements are similar to the traditional tourist travels in someone's leisure time;

$\checkmark$ they build and improve the loyalty of employees and workers to the companies, their clients and partners;

$\checkmark$ they are meant beforehand for those employees who meet certain criteria and perform clear goals whose achievement can be measured and qualified within the working process. Incentive travels are planned and complied with the participants and the company executives.

As a whole, the positive effects of applying incentive travels should be guaranteed in a strategic aspect by the preparation of suitable programmes for incentive travels. These programmers are of significant importance because they improve participants' attitudes towards travels as a reward and develop their company loyalty. The overall success of an incentive programme can be measured if it provides thoughtful and worth-remembering trips. Each incentive travel needs to be prepared in compliance with these leading values because the participants have the expectation to have common experience and enjoy these trips after they have tried to achieve certain corporate goals.

By large, the types of programmes for incentives can be categorized as encouraging (for recognition), motivating, for increasing loyalty and team-building. Incentive travels are gifts or awards meant for company employees, clients or consumers. Package incentive travels are viewed as a modern management tool which is doomed to motivate and stimulate the stakeholders involved in the overall process of the company. The design and preparation of incentive travels is a proven 
effective award, especially suitable for stimulating the sales team or the customer loyalty programme. A group travel offers unique opportunities for creating incomparable interactions, relations and networks through building participants' strategic loyalty, together with attracting new clients and sales team members and sales growth. Worldwide the incentive travels are recognized as an effective tool with significant power to influence:

- higher productivity;

- improved motivation for work, elevating and strengthening the team spirit;

- increased customer loyalty and staff retention;

- increased sales and attraction of new business forms.

On-site experience is of crucial importance for the success of incentive travels. Participants in such programmes must be offered unique experience which exceeds their usual expectations and complies with the efforts they put in the working activities. Meeting these important conditions guarantees the achievement of the goals set in any incentive programme. By large, sponsors of similar programmes demand that the participants receive and acquire tourist experience that will later perform the role of an effective motivator guiding their business results. Participants, in turn, require from incentive travels experiences that are equal to the time and effort they put in performing their duties at work. The proportion in respect to time and efforts is important for achieving high levels of inspiration and satisfaction with taking part in incentive travels. The overall experience of an incentive program could be assessed in the following three basic trends (Nasution, 2016):

- content (compatibility) - it is achieved through significant compatibility of desires and expectations to the goals of the incentive programme. By using questionnaires, interviews and informal surveys one can determine the values, interests and preferences that incentive travels need to satisfy in order to fulfill successfully their stimulating role. The all-embracing worth of every incentive programme is formed by clear, fair and achievable goals, effective communication with the participants and constant feedback concerning the degree of its effectiveness. This adds meaningfulness to the programme and guarantees long-term, active and resultative participation in it;

- motivation - it is often that incentive travels are based on one-size-fits-all approach. The design of the programme should motivate all participants and should offer a complete event from start to end, one that strengthens the motivation for participation in event incentive travels. The result is experience which is truly inspiring and at the same time stimulating for every unique audience;

- unforgettableness - exciting experiences have different value and worth (short- and longtime), both for the participants and the organizers. The whole experience acquired by the participants, like the programme itself and its end, have crucial importance for those of them who perform and achieve their goals successfully. Reward travels are a reminder for achieved results. Therefore, those who plan the incentive programs need to study not only the experience gathered on site, but also do research on the experiences in a broader context aimed at improving them.

\section{Trends in incentive travel industry}

Incentives are corporate-sponsored trips for employees, distributors or clients. Unlike the other types of MICE, incentives are focused on leisure rather than business. Companies use them to: reward performance; motivate work effort; create company loyalty. A survey of the Incentive Research Foundation (IRF, 2019) outlined the leading changes in the field of incentive tourism which have an impact on: companies providing trips as a reward; the character and type of the incentive products and services; the activity of the organizers of similar trips. The more significant trends relate to:

$\checkmark$ The processes of mergers and acquisition which occur in global economy. At the end of 2018 one observed instability on the world markets as a result of the volatility on the US stockexchange indices. This volatility provoked discussion about the economic prospects and their 
impact on non-cash rewards for employees, including incentives. The condition of their market can be characterized as neutral. Worldwide almost $1 / 3(32 \%)$ of those planning incentives claim that national economies have a positive influence on their reward programmes, whereas $29 \%$ think that the impact is negative. However, the counteractive powers in economy intensify one's worries in respect to market instability even though $84 \%$ of the enterprises use non-cash rewards, including incentives. The power of the market continues to stimulate mergers and acquisitions in all business sectors. A significant part of the enterprises using non-cash rewards as an element of their human capital or marketing strategy, look for help from outside in implementing incentive programmes. The tendency is for a growing market and increased demand for such services; hence this will go on in the future as well. This trend has been encouraged by an increase of the interest in the incentives market on behalf of the private sector, as well as the necessity for differentiating and providing various forms of value and utility, including by use of reward travels.

$\checkmark$ Physical security and safety, as well data security are of paramount significance for sellers and buyers of incentive travels. After satisfying these basic needs, people are able to proceed to higher levels of existence, including the feeling of belonging, self-respect and self-perfection. The tourist industry motivates the transition of individuals between these levels, yet, the focus on safety and security continues to be a factor of key impact. A new element is to guarantee not only the physical dimensions of security and safety, but also their digital manifestation. The threat of terrorism is still a main issue and it affects the programmes for incentives.

$\checkmark$ The incentive travels provided by employers is stronger than it has ever been. Reward trips are a means for creating direct relationships, stimulating one's participation, sharing knowledge and commitment to implementing company goals and mission. Incentives strengthen company culture and the relations between sellers and organizers of reward trips on the one hand and employers, managers and employees on the other; they generate "a sense for goals". It is often that managers are confused by company culture because a considerable part of it is encoded in nonverbal behaviour, thinking and social models. Managing this culture in the right way can encourage changes that would be able to create successful organizations, this can happen even in insecure, destructive and complicated conditions. The combination of economic stimuli with recognition and well-designed non-cash rewards (incentives) encourages the behaviour of "corporate citizenship" which claims that a business entity is accepted as a member of the social community instead of its counterpoint. Incorporating business into the social life and social development of the public is one of the primary tendencies in the business philosophy of the late $20 \mathrm{C}$ and is actually a modern interpretation of mercantile thinking. Similar behaviour and attitudes create working environment and culture that attract and retain the best and talented employees in an organization.

$\checkmark$ Predictable analysis and artificial intelligence which considerably change the aspects of management of human capital. In the field of incentives they help to design personalized programmes for corporate holidays prepared and presented in a facilitated way that encourages participation and leads to better results.

$\checkmark$ Incentive travels are affirmed as a factor of considerable contribution. The forecasts envisage sustainability of this tendency in the future too because: company budgets for such travels increase with about $5 \%$ and support the growth of the incentive-travels industry; there is an increased interest in reward travels; the in-company and the public interest in accepting incentives are growing; the average costs for buying such programmes are increasing as well. One of every two buyers confirms that the total budget for stimulating travels goes up. More than half of all buyers plan to increase the number of employees who meet the requirements to receive a reward travel. Today the attitudes and perceptions to such trips are more positive and favourable than those ten years ago. Many of the programmes are meant for travels far away from home; yet, the interest in long-haul incentives is growing. North America is a leading destination for incentives for US owners and producers of programmes. There follow the Caribbean, Western Europe, the Pacific region (Hawaii) and Australia. Paris, Cancun and the Bahamas rank highest as the most popular 
destinations for incentives.

$\checkmark$ New unique places like Iceland, Columbia and Eastern Europe are rapidly drawing interest and attention as destinations and are being involved in incentive programmes. Not so long ago hardly anyone would look at destinations such as Krakow, Glasgow, Porto or Split for huge international events and incentives. The industry was pretty much dominated by the big six in Europe: London, Barcelona, Berlin, Paris, Frankfurt and Amsterdam. Nowadays, corporates and incentive travel organizers are willing to take their business to many smaller cities or more exotic destinations. Cities such as Budapest, Prague, Ljubljana, Gdansk or Riga are gaining popularity. In the last couple of years, eastern European cities and destinations have hugely benefited from significant infrastructural developments as well as enormous investment. Many new cutting-edge venues and modern hotels were built in countries like Poland, Estonia, Slovenia or Latvia. Also, the biggest hotel chains such as IHG or Marriot are now staying behind the trend and constantly opening new eastern European properties to meet the demand. Majority of international companies are now choosing Eastern European cities as an alternative of their incentives trips to the overcrowded and overpriced destinations of the West.

$\checkmark$ Counteracting factors to the growth of incentives. The number of buyers (of incentives) who have undertaken steps for cutting costs increases every year: from $73 \%$ in $2017,78 \%$ in 2016 , $80 \%$ in 2017 and $82 \%$ in 2018. With the growing prices of fuel to keep the costs for air transport has been the main priority in determining the budgets for incentive-travels programmes. The main challenges in financing these programmes are the expenditures for air fare, the national political conditions and the threat of terrorist attacks. Such challenges are characteristic of all-inclusive destinations because $41 \%$ of the buyers indicate package trips as the basic way for optimizing guest experiences when cutting the costs for incentives is quite necessary. Political and social issues like change of government, strikes, regulations concerning border security have also been analyzed when preparing and implementing incentive programmes. The basic strategies for cutting costs for such programmes are: choosing cheaper destinations, less programmes and shorter stays, decreasing the number of the participants.

$\checkmark$ Transforming experiences through incentives will continue to assert themselves because they offer memorable and unique experience. It binds participants in meaningful relationships that lead to personal development and self-growth. Parallel to it one's welfare is improved, sustainability of personal and corporate development is achieved, company community is strengthened and one's self-realization as personality is bettered. Participants want more cultural and authentic experiences. People want to go to interesting museums, learn a foreign language or local handicraft or access the famous attractions of the place. Transforming travels pose a challenge to participants on a personal level, creating emotions and experiences by means of storytelling. This tendency is growing together with age advancement and the process of enriching the participants' tourist experience.

$\checkmark$ Flexibility, experience and design imperative in planning incentive programmes. They must change constantly in order to constantly engage participants in transforming experiences in various ways. The future company employees are the millennials whose tourist experience is sufficiently rich and diverse. They have already been to Paris, Amsterdam and London and what they want is discover new destinations. Incentives meant for the millennials should offer various destinations and experiences which transform in a new way. Therefore, programs that combine experimental elements (wellness, yoga), local excursions (culinary tours, out-door hiking) with possibilities for meaningful interaction between participants need to be part of the range of incentive-travel design. It is necessary to constantly test new ideas from various spheres in order to design incentives that comply with the dynamic changes.

\section{Incentive programmes in Bulgaria - potential and key challenges}

Incentive programmes are not only a tool for improving company productivity, but also an intelligent investment in promoting national tourism. Adventures, experiences and adrenaline are 
only some of the main characteristics of a good incentive travel. Similar programmes should include also extra (accompanying) elements for designing recreational and creative holidays. MICE industry to which such travels belong attracts the interest of national governments, regional tourist organizations, large companies, large and medium enterprises and individual entrepreneurs. To develop incentive tourism Bulgaria has a vast potential of tourist attractions and cultural initiatives, hence it can be an important participant on the incentives market. The geographic and historical richness of the country offers favourable opportunities for creating various and interesting programmes encompassing existing historical and numerous natural sites which are part of the world cultural and natural heritage. In order to tap into the natural, historical and cultural potential of the country of crucial importance is the role of central and local authorities and specialized tourist organizations. The inbound, outbound and domestic types of incentive tourism have an impact on the growth of the whole tourist sector in our country.

The region of Eastern Europe lies in the scope of interest and attention of organizers of incentives programmes, thus Bulgaria has the chance to benefit from this favourable tendency. As one of the oldest states on the European continent, the country has various tourist attractions that can be used both as a marketing tool and part of incentive programmes. Cities like Plovdiv, Veliko Tarnovo, Sofia, Varna, Nessebar and other large and small places in central, mountain and seaside areas of the country (Bansko, Tryavna, Koprivshtitsa, Zheravna, Kovachevitsa), recommended by Michelin Travel Partner, are suitable for incentive travels. To create an image as attractive destinations in this trend requires the coordinative functions and support on behalf of the central authorities and the Ministry of tourism, as well as investments in specialized training and staff, professional attitude and work with specialists who are involved in designing and implementing incentive travels. The crossroad location of the country and the traditional Bulgarian hospitality add extra stimulation for promoting it as an incentive destination; yet, what is necessary are actions and measures for rediscovering Bulgaria as a location for stimulating travels designed and offered in the form of specialized package tourist products. Their effective realization of the market of incentives requires cooperation and coordination between national and regional organs and institutions, municipal and professional organizations, organizers of incentive-travels programmes within the country and abroad, encouragement of inbound and domestic incentive travels at the expense of outbound ones.

On national level incentive tourism has been ignored and is not defined as a priority tourist product. No energetic actions have been taken for promoting Bulgaria as a destination of MICE tourism and for incentive travels in particular. At the time of the Bulgarian chairmanship of the EU Council in 2018 favourable opportunities were missed for promoting and presenting the country as a serious and attractive MICE destination. The designed and constructed comparatively good hotels have comfortable locations; yet, they do have insufficient of little number of conference halls meant to hold events as an element of incentive programmes. In Bulgaria the companies that deal with organizing and implementing such programmes, in combination with special events, face a dilemma in respect to how to choose a place for accommodation: if rooms are suitable, the conference hall is not and vice versa. Hoteliers on the Black-sea coast are not particularly interested in prolonging the tourist season by attracting various events or providing accommodation for incentive programmes in the months with less tourist. Hence, the neglect of the Bulgarian seaside as a variant for incentive tourism on behalf of organizers.

Serious impediments to the development of tourism in Bulgaria, including to incentive travels, is created by transport infrastructure. Our country is one of the EU members with the most low-quality characteristic features of transport infrastructure. This was stated in a report of the European Commission (EU, 2019) which reviews and classifies the condition of the transport sector in the EU member countries. The overall rating of the Bulgarian transport system is "relatively low". The only worse roads are those in Latvia, Malta and Romania. A slight improvement has been noted in the infrastructure of air transport and ports. The Bulgarian transport infrastructure in all 
categories (rail, air and sea) is among the least developed ones. Bulgaria ranks fourth in bad road infrastructure, our ports are also below the average level in the European Union - in this category our country ranks last but one, it is only Romania that is assigned a lower grading. Bulgarian airports and agencies that serve air transport have marked progress, however, we rank $25^{\text {th }}$ among 28 countries total. Railway infrastructure has worsened according to data in the report made in 2019 as compared to that the year before. Then Poland followed Bulgaria, but this year the country has overtaken Bulgaria concerning this indicator. The number of casualties on the motorway is the highest in EU - 96 casualties per population of a million every 30 days (the average for Europe being 49). Our country ranks last also by customer satisfaction with railway transport, customers being more satisfied with air transport. In respect to this indicator, Bulgaria ranks $10^{\text {th }}$ among the 28 EU member countries. As for customer dissatisfaction with public1transport our country ranks sixth.

\section{Recommendations for the development of incentive tourism in Bulgaria}

In the Updated national strategy for sustainable development of tourism incentive tourism is presented as a specialized niche product and part of MICE tourism (Ministry of Tourism, 2017). The following activities are recommended for its development: organizing and holding specialized exhibitions and attracting international companies which hold events of international, national and regional importance; providing incentive travels as an effective measure for limiting the negative effects of seasonality; organizing advertising campaigns for promoting the potential for development of incentive tourism; making promotional clips and advertising spots for incentives in Bulgaria which are meant for spreading on social networks; combining incentive tourism with other more elitist types and forms of tourism (spa and wellness, wine and culinary tourism and others) aiming at the creation of a customer sense of an exceptional-quality tourist product. To these activities one could add the following recommendations for efficient use of the tourist potential of Bulgaria and its promotion as a destination for incentive travels:

$\checkmark$ Participation in the two largest specialized exhibits IMEX in Frankfurt and IBM in Barcelona and taking marketing initiatives meant for a particular target audience interested in incentives;

$\checkmark$ Advertising and promoting the country to established organizers of events and incentive programmes in a regional "package" as South-Eastern Europe and affirming a joint trademark (for ex. Sweden and Denmark, irrespective of the differences between them, are famous for the brand "Scandinavia" in the name of common growth of the tourist industry, including incentives).

$\checkmark$ Enlivening the activity of the Bulgarian congress Bureau (BCB) established in 2016 so that it can implement its mission for "supporting congress tourism in the country through making popular and offering in Bulgaria and abroad congress and exhibition venues, specialized services for holding congress events, trade fairs and exhibits, corporate and incentive travels". The BCB Association can take the initiative and invite tour operators and organizers of incentives for holding fam-trips in Bulgaria. These are classic promotional tours aimed at making foreign companies in the tourist branch familiar with the merits of Bulgaria as a destination for incentive and event tourism.

$\checkmark$ Taking actions for membership in the Society for Incentive Travel Excellence (SITE) which develops a global network of professional organizers of incentive travels and motivating events. The SITE is the only business events association dedicated exclusively to the global incentive travel industry. The professional association was founded in 1973, with more than 2500 members in more than 90 countries, working in corporations, agencies, airlines, cruise companies and across the entire destination supply chain. The SITE Foundation was established to raise funds and support research, education and advocacy projects on behalf of the incentive travel industry. The money raised by the SITE Foundation makes it possible to make the business case for incentive travel and highlight the transformational potential of travel experiences on individuals, enterprises 
and communities. The SITE Foundation has funded certification for mid-manager level incentive travel professionals.

$\checkmark$ Designing incentive programmes that combine training and participation in events (conferences, meetings and other) for presenting new company products, services, production processes or strategies. In combined incentive travels it is necessary to underline the role and significance of the historical and cultural incentives as a ground for a country's specialization in the sphere of incentive tourism. Especially suitable for it is the combination of experiential and wellness travel for creating an unforgettable and special corporate event for immersing in the culture and history of the place for visiting. Similar incentive programmes could involve: courses in traditional Bulgarian crafts, hiking in attractive natural sites, spa and swimming plus yoga, getting familiar with Bulgarian folk traditions (Yancheva, 2012; 2013), cooking Bulgarian dishes, taking part in folk festivals (Yancheva, 2014) and holidays as well as in traditional agrarian activities, local rituals and customs for preparing food and drinks, sport events and others.

The future of incentive travels in Bulgaria is closely tied with changing the image of our country as a tourist destination. The initiatives started by the governing bodies (both on central and local level) and tourist non-governmental organizations are able to have an impact on the common image of Bulgaria in coordination with organizers of incentives programmes (Bulgarian and international), destinations and places for accommodation which are suitable for incentive trips. The traditional Bulgarian hospitality, rich history, customs and traditions form the main advantages of incentive tourism in the country as part of the business, and at the same time, a key element in the national tourist strategy. Therefore, the successful implementation of the activities planned in the strategy need to be carried out parallel to the implementation of the Trans-European Transport Network policy (TEN-T). This policy could pave the way towards the future of Bulgaria's transport system, in particular through low-emission facilities, new generation services concepts and innovation. This includes the construction of road and rail infrastructure, building the links to the Western Balkans and exploiting the potential of the Black Sea and the Danube. Doing so would allow Bulgaria to benefit from its central location as a transit country on the future Alpine-West Balkans Rail Freight Corridor. The remaining priority is to develop the Corridors of the TEN-T Network ("Orient/East-Med" and "Rhine-Danube"), as well as the connections with the WesternBalkan countries. The development of the road infrastructure should tackle existing imbalances between regions, thus improving connectivity between northern and southern Bulgaria. Higher revenues from the electronic vignette system are expected to allow safer road infrastructure, completion of missing network sections, faster deployment of intelligent transport systems and interfaces with other modes of transport.

Reward travels are part of the system for stimuli in an organization and being such it is of primary importance to have quality of the services provided in them. Thus they have to inspire their participants and motivate them for future actions for achieving company goals. In incentive industry the quality is even more important than in leisure tourism. Incentive travellers generally have higher expectations. Incentive buyers require high quality in all areas, such as: high level of customer service; safe and comfortable transport; clean and comfortable accommodation; good catering; event and meeting facilities with good Internet access and Wi-Fi. Satisfying these requirements needs to be integrated in the programmes for inbound, outbound and domestic incentive travels in our country.

\section{Conclusion}

Bulgaria has considerable potential for incentive tourism. The country also has competitive advantages in respect to: natural resources, rich culture, diverse historical heritage, a number of holiday and folk events in the calendar, security and safety. Apart from it, incentive-travel programmes in Bulgaria could combine stay in: urban and rural areas, tourist centres and resorts, recreation (relaxation) activities and more active (sport) exercises and others. Despite all this, the 
common image of the country as a destination for cheap sea holidays does not allow to clearly outline and define the advantages of incentive tourism. This leads to missing benefits and considerable lagging behind the competitors in the trend. The interests and tendencies in incentive travels to destinations in Eastern Europe are real and important; therefore Bulgaria needs to benefit from them as effectively as possible. Established positions of the country as a vacation destination which extensively offers the all-inclusive type of stay additionally motivates the process of designing and implementing incentive travels. Thus the effective communication programme stimulating the market of incentives in our country needs to be based on the active interaction between public and professional organizations, the preparation and spreading of suitable advertising materials (print and electronic) with exciting messages to the stakeholders.

\section{References}

1. European Union. (2019). Transport in the EU: Current Trends and Issues. March 2019. Directorate-General for Mobility and Transport (DG MOVE) of the European Commission. [Online] Available from: https://ec.europa.eu/transport/sites/transport/files/2019-transport-inthe-eu-current-trends-and-issues.pdf [Accessed 05/10/2019].

2. Events Industry Council. (2018). Global Economic Impact of Business Events. Oxford Economics, November 2018. [Online] Available from: https://www.the-iceberg.org/research/ 2018-global-economic-significance-of-business-events/ [Accessed 01/10/2019].

3. Goldblatt, J., \& Nelson, K. (2001). The International Dictionary of Event Management. (2 ${ }^{\text {nd }}$ ed.). New York: John Wiley \& Sons.

4. Ministry of Tourism. (2017). National Strategy for Sustainable Tourism Development in the Republic of Bulgaria 2014-2030. ESTAT Ltd. [Online] Available from: http://www.tourism. government.bg/sites/tourism.government.bg/files/ uploads/strategy-policy/pril9.nsurtb_20142030-updated_mt-final.pdf [Accessed 29/09/2019].

5. Nasution, H. (2016). Effectiveness of incentive travel program more meaningful, motivational and memorable. [Online] Available from: https://www.researchgate.net/ [Accessed 01/10/2019].

6. Pizam, A., \& Holcomb, J. (eds.) (2017). International Dictionary of Hospitality Management. Abington [England]: Routledge.

7. Society of Incentive Travel Executives. (2019). About SITE - Who we are. [Online] Available from: https://www.siteglobal.com/p/cm/ld/fid=1[Accessed 29/09/2019].

8. Swarbrooke, J., \& Horner, S. (2001). Business Travel and Tourism. London: Routledge.

9. The IRF Trends Study. (2019). Incentive Research Foundation. [Online] Available from: https://theirf.org/research/irf-2019-trends-study/2617/ [Accessed 26/09/2019].

10. Yancheva, K. (2012). 'Otsenka na vazmozhnostite na balgarskiya folklor za realizirane na kulturno-poznavatelni turisticheski patuvaniya.' Izvestiya Journal of University of economics Varna, 4, pp. 99-109.

11. Yancheva, K. (2013). 'Turisticheski produkti, bazirani na osnovata na balgarskiya folklor.' Proceedings of International Scientific Conference "Sustainable Tourism 2020", October, 2013, College of Tourism - Varna, Varna: Science and Economy, pp. 219-228.

12. Yancheva, K. (2014). 'Aspekti na usavarshenstvane na festivalniya turizam v Bulgariya.' Izvestiya Journal of University of economics - Varna, 4, pp. 52-67. 